\title{
Peningkatan Hasil Belajar IImu Pengetahuan Sosial pada Materi Kenampakan Alam dan Keadaan Sosial Negara Tetangga Melalui Snowball Throwing
}

\author{
Sohifah \\ SDN 1 Kamulan Kec. Durenan Kab. Trenggalek \\ Email : sohifahspd@gmail.com
}

\begin{abstract}
Abstrak: Pembelajaran di kelas pada umumnya masih menggunakan metode pembelajaran klasik yaitu ceramah. Siswa sebagai subjek yang belajar dan menganggap hanya guru sumber mereka belajar. Metode pembelajaran ini krang efektif bagi siswa sehingga siswa hanya pasif di kelas. Penelitian ini bertujuan untuk meningkatkan Hasil Belajar siswa pada mata pelajaran IImu Pengetahuan Sosial (IPS) pada materi kenampakan alam dan keadaan sosial negara tetangga menggnakan permainan Snowball Throwing pada siswa kelas VI di SDN 1 Kamulan. Penelitian ini menerapkan metode penelitian tindakan kelas dengan dua siklus. Hasil penelitian menunjukkan bahwa pembelajaran Snowball
\end{abstract}

\begin{tabular}{l}
\hline Tersedia Online di \\
\hline http://journal.unublitar.ac.id/pendidi \\
\hline kan/index.php/Riset_Konseptual \\
\hline Sejarah Artikel \\
Diterima pada : 03-01-2020 \\
Disetuji pada : 07-01-2020 \\
Dipublikasikan pada : 31-01-2020 \\
\hline Kata Kunci: \\
Hasil belajar, kenampakan Alam, Snowball \\
Throwing. \\
DOI: \\
\hline http://doi.org/10.28926/riset_konseptual.v4 \\
i1.173 \\
\hline
\end{tabular}

Throwing dapat meningkatkan hasil belajar IPS siswa Kelas VI di SD Negeri 1 Kamulan. Hal tersebut dapat dilihat Nilai rata-rata siklus 1 69,44 dan siklus $2 \quad 77,22$ Ketuntasan belajar siklus $173 \%$ dan siklus $289 \%$.

\section{PENDAHULUAN}

Strategi pembelajaran ekspositori masih sangat umum diterapkan di kelas. Strategi ini merupakan cara mengajar dengan penyampaian materi secara lisan dalam. Strategi ini dapat dikatakan sebagai strategi ceramah yang berarti alat utama dalam pengajaran tersebut menggunakan tutur kata dengan lisan (Wina Sanjaya, 2006: 179). Guru menyadari bahwa selama ini dalam menyampaikan mata pelajaran IPS selalu mendominasi jalannya pembelajaran. Guru menerangkan materi pembelajaran dengan ceramah, siswa mendengarkan kemudian siswa diberi tugas untuk menuliskan pokok bahasan yang penting. Hasil yang diperoleh kurang maksimal, karena siswa yang cerdas akan lebih mudah memahami, sedangkan siswa yang kemampuannya rendah, mengandalkan bantuan temannya yang lebih pandai. Hal ini terjadi juga pada materi IPS Kenampakan Alam dan Keadaan Sosial Negara Tetangga.

Sebelum dilakukan penelitian, diketahui hasil belajar siswa memperoleh skor tertinggi 80 sebanyak 3 anak (16,66\%), skor 70 sebanyak 7 anak $(38,89 \%)$ skor 60 sebanyak 6 anak (33,33\%), skor 50 sebanyak 2 anak (11,11\%). Rata-rata skor siswa pada kondisi awal ini sebesar 66,11. Sedangkan ketuntasan belajar hanya mencapai 10 anak (55,5\%) sehingga dikatakan belum tuntas.

Dari pengalaman tersebut, maka guru sebagai peneliti ingin meningkatkan hasil belajar mata pelajaran IPS dengan merubah strategi pembelajaran yang selama ini telah dilakukan. Strategi pembelajaran merupakan suatu cara atau metode yang dilakukan guru dalam melaksanakan proses pembelajaran untuk mencapai tujuan pembelajaran. Untuk memperoleh hasil belajar yang maksimal seorang guru harus mempunyai kemauan untuk memperbaiki proses belajar mengajar menjadi 
pembelajaran. Agus Priyono ( 2009:12) menyatakan pembelajaran sebagai upaya untuk mengorganisir lingkungan terjadinya pembelajaran dengan menyediakan fasilitas belajar yang dilakukakan guru untuk kegiatan belajar siswa.

Dari uraian di atas, melalui strategi pembelajaran yang tepat kiranya dapat meningkatkan hasil belajar perseta didik yang diharapkan dalam mencapai tujuan pembelajaran pada semua kompetensi dasar setiap muatan pelajaran. Menurut Gropper (Hamzah B Uno 2014: 1) mengatakan bahwa strategi pembelajaran merupakan pemilihan atas berbagai jenis latihan tertentu yang sesuai dengan tujuan pembelajaran yang ingin dicapai. Oleh karena itu, penelitian ini bertujuan untuk meningkatkan hasil belajar siswa menggunakan permainan snowball throwing agar siswa merasa semangat dan tidak bosan dalam mempelajari materi IPS Kenampakan Alam dan Keadaan Sosial Negara Tetangga.

Pembelajaran Snowball Throwing merupakan pembelajaran aktif yang melibatkan seluruh siswa untuk mengetahui konsep pemahaman materi yang sulit kepada siswa yang bertujuan untuk untuk mengetahui sejauh mana siswa memahami materi yang telah disampaikan. Menurut Miftahul Huda (2016: 226) pada pembelajaran Snowball Throwing siswa dibagi menjadi beberapa kelompok yang masing-masing kelompok diwakili ketua kelompok untuk mendapat tugas dari guru, selanjutnya setiap siswa diminta untuk membuat pertanyaan diselembar kertas yang yang kemudian dibentuk seperti bola (kertas pertanyaan). Setelah itu bola kertas tersebut dilempar ke siswa lain. Setiap siswa harus menjawab pertanyaan dari bola kertas yang didapatkan.

Dari pendapat di atas dapat disimpulkan bahwa pembelajaran snowball throuwing diawali dengan membentuk beberapa grup, masing-masing ketua grup mendapat tugas dari guru yang selanjutnya disampaikan kepada teman sekelompoknya kemudian masing-masing siswa membuat pertanyaan diselembar kertas dan diremas dibentuk seperti bola, kemudian dilempar-lemparkan kepada temannya. Bagi siswa yang menerima lemparan bola harus menjawab pertanyaan yang terdapat pada bola kertas tersebut.

\section{METODE}

Penelitian ini menerapkan metode penelitian tindakan kelas yang dilaksanakan dengan dua siklus dengan menerapkan permainan snowball throwing. Penelitian ini juga termasuk dalam metode Deskriptif Kualitatif untuk menjabarkan hasil belajar siswa. Penelitian tindakan kelas ini dijalankan dengan empat langkah sebagai berikut: tahap perencanaan, tahap pelaksanaan, tahap pengamatan, dan terakhir tahap refleksi, Suharsimi Arikunto (2014 : 16).

Untuk mengetahui tingkat keberhasilan siswa setelah proses belajar mengajar pada setiap siklusnya, maka perlu dilakukan analisis dengan cara memberikan pengayaan berupa pemberian tes tulis dengan beberapa soal pada setiap akhir pembelajaran pada pertemuan ke 2 (dua) setiap siklus. Analisis ini dihitung dengan menggunakan statistik sebagai berikut:

a. Pengolahan Nilai Tes Pilihan Ganda

Nilai akhir diperoleh dengan cara membagi jumlah skor jawaban benar dengan skor ideal kemudian mengalikannya dengan 100. Pengolahan nilai menggunakan rumus berikut:

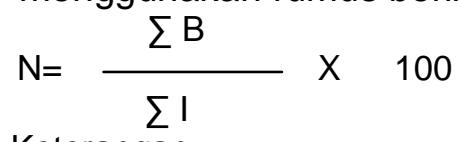

Keterangan :

$\mathrm{N}$ : skor akhir

$\sum$ B: skor jawaban benar

$\sum$ I: Jumlah skor ideal atau skor maksimal

100: standar skor Ideal

b. Menentukan rata-rata skor 
Skor rata-rata didapat dengan cara menjumlah nilai semua siswa membagi jumlah nilai dengan jumlah peserta tes. Untuk itu perhatikan rumus berikut.

$\dot{M}=\frac{\sum N S}{\Sigma S}$

Keterangan :

M : Nilai rata-rata

$\sum$ NS : nilai semua peserta tes keseluruhan

$\sum S \quad$ : peserta tes keseluruhan

c. Menentukan Persentase Ketuntasan Belajar

Persentase ketuntasan belajar nerupakan tolok ukur keberhasilan pembelajaran. Apabila ketuntasan belajar telah mencapai $85 \%$ dari jumlah siswa, pembelajaran telah tuntas dan dapat dilanjutkan. Persentase ketuntasan belajar ditentukan dengan rumus berikut ini.

$\dot{T}=\frac{\Sigma \mathrm{T}}{\Sigma \mathrm{S}} \times 100 \%$

Keterangan :

$\dot{\dagger} \quad$ : Persentase Ketuntasan

$\sum \mathrm{T}$ : Jumlah siswa yang telah tuntas

$\sum$ S:Jumlah peserta sisik

$100 \%$ : perkalian tetap

HASIL DAN PEMBAHASAN

\section{Siklus I}

Tabel 1. Hasil evaluasi siswa dalam memahami kenampakan negara-negara Asia Tenggara pada siklus 1

\begin{tabular}{|c|c|c|c|c|}
\hline Nomor & Skor & Frekuensi & NF & Prosentase \\
\hline 1 & 90 & 0 & 0 & 0 \\
\hline 2 & 80 & 5 & 400 & $27,78 \%$ \\
\hline 3 & 70 & 8 & 560 & $44,44 \%$ \\
\hline 4 & 60 & 4 & 240 & $22,22 \%$ \\
\hline 5 & 50 & 1 & 50 & $5,56 \%$ \\
\hline \multirow{2}{*}{\multicolumn{3}{|c|}{\begin{tabular}{c|c} 
Jumlah & \\
Nilai Rata-rata
\end{tabular}}} & 1.250 & $100 \%$ \\
\hline & & & 69,44 . & \\
\hline
\end{tabular}

Tabel di atas menunjukkan nilai yang diperoleh siswa dalam pembelajaran dengan materi kenampakan alam negara-negara Asia Tenggara pada Siklus I adalah nilai tertinggi 80 sebanyak 5 anak (27,78\%), nilai 70 sebanyak 8 anak $(44,44 \%)$, nilai 60 sebanyak 4 anak $(22,22 \%)$, yang mendapat nilai 50 ada 1 orang anak $(5,56 \%)$ Nilai rata-rata siswa pada Siklus I ini sebesar 69,44.

Selanjutnya ketuntasan belajar siswa terhadap materi kenampakan alam dan keadaan sosial negara tetangga secara individual pada siklus I dapat dilihat pada tabel 2 berikut ini.

Tabel 2. Penguasaan siswa dalam memahami materi kenampakan alam negaranegara Asia Tenggara pada Siklus I

\begin{tabular}{|c|c|c|c|l|}
\hline Nomor & Skor & Frekuensi & prosentase & \multicolumn{1}{|c|}{ Ket. } \\
\hline 1 & 90 & 0 & 0 & 0 \\
\hline 2 & 80 & 5 & $27.78 \%$ & Tuntas \\
\hline 3 & 70 & 8 & $44,44 \%$ & Tuntas \\
\hline 4 & 60 & 4 & $22,22 \%$ & Tidak Tuntas \\
\hline 5 & 50 & 1 & $5,56 \%$ & Tidak Tuntas \\
\hline Jumlah & 18 & $100 \%$ & \\
\hline
\end{tabular}


Tabel di atas menunjukkan bahwa ketuntasan belajar terhadap materi kenampakan alam negara-negara Asia Tenggara dengan pembelajaran Snowball Throwing pada siklus I adalah sebanyak 13 anak (72,22\%). Secara klasikal belum tuntas karena siswa yang telah mencapai KKM belum mencapai $85 \%$.

Guru selaku peneliti telah melaksanakan pembelajaran sesuai dengan Rencana Pelaksanaan Pembelajaran. Guru senantiasa memfasilitasi pembelajaran siswa dengan cara berkeliling dari satu kelompok menuju kelompok lain. Ketika mendatangi suatu kelompok selalu menanyakan kesulitan yang dialami oleh kelompok tersebut. Apabila ada kelompok yang bertanya lagi guru pun mendatangi kelompok tersebut. Pada saat ketua kelompok menjelaskan materi yang disampaikan guru, belum semua anngota kelompok aktif menanggapi dengan sungguh-sungguh, masih ada siswa yang bercanda.

Pada waktu membuat satu pertanyaan menyangkut materi yang dibahas, siswa yang tidak memperhatikan dengan sungguh-sungguh mereka bingung selalu bertanya pada temannya sehingga suasana kelas menjadi agak gaduh. Ketika tes dilaksanakan siswa yang kurang serius dan tidak sungguh-sungguh dalam pembelajaran tampak kebingungan. Hasil ulangan siswa dengan konsentrasi belajar rendah ini cenderung rendah. Hasil belajar siswa pada siklus I ini belum mencapai ketuntasan klasikal. Siswa yang tuntas belajar sebanyak 15 orang (72\%). Ketuntasan belum mencapai minimal $85 \%$. Oleh karena itu, penelitian ini perlu dilanjutkan ke Siklus II.

\section{SIKLUS 2}

Pada Siklus 2 suasana kelas tanpak lebih tenang, siswa lebih serius dalam mengikuti pembelajaran. Pada saat guru memberikan penjelasan tentang kompetensi dasar dan tujuan pembelajaran siswa memperhatikan dengan sungguh-sungguh. 2) Ketika membuat satu pertanyaan sudah tidak terlihat siswa yang mondar-mandir. Siswa lebih konsentrasi dalam membuat pertanyaan mengenai kondisi sosial negaranegara tetangga. 3) Hasil Evaluasi Individu. Hasil evaluasi siswa dalam pembelajaran kenampakan alam dan keadaan sosial negara-negara tetangga pada siklus II diperoleh data tingkat penguasaan materi seperti pada tabel 3 berikut ini.

Tabel 3. Hasil evaluasi siswa dalam memahami kenampakan negara-negara tetangga pada siklus 2

\begin{tabular}{|c|c|c|c|c|}
\hline Nomor & skor & Frekuensi & $\mathrm{NF}$ & Prosentase \\
\hline 1 & 100 & 2 & 200 & $11,11 \%$ \\
\hline 2 & 90 & 2 & 180 & $11,11 \%$ \\
\hline 3 & 80 & 5 & 400 & $27,78 \%$ \\
\hline 4 & 70 & 7 & 490 & $38,89 \%$ \\
\hline 5 & 60 & 2 & 120 & $11,11 \%$ \\
\hline \multicolumn{2}{|c|}{ Jumlah } & 18 & 1.390 & $100 \%$ \\
\hline \multicolumn{3}{|c|}{ Nilai Rata-rata } & 77,22 & \\
\hline
\end{tabular}

Tabel di atas menunjukkan nilai yang diperoleh siswa dalam pembelajaran dengan materi keadaan sosial negara-negara tetangga pada siklus II adalah nilai tertinggi 100 sebanyak 2 anak $(11,11 \%)$, nilai 90 sebanyak 2 anak $(11,11 \%)$ nilai 80 sebanyak 5 anak (27,78\%), nilai 70 sebanyak 7 anak (38,89\%), yang mendapat nilai 60 ada 2 orang anak (11,11\%). Nilai rata-rata siswapada Siklus II ini sebesar 77,22.

Selanjutnya penguasaan siswa terhadap materi keadaan sosial negara-negara tetangga secara individual pada siklus II dapat dilihat pada tabel 4 berikut ini.

Tabel 4. Penguasaan Materi Kenampakan alam dan keadaan sosial negara-negara tetangga pada Siklus II

\begin{tabular}{|c|c|c|c|l|}
\hline No. & Skor & Frekuensi & Prosentase & Ket. \\
\hline 1 & 100 & 2 & $11,11 \%$ & Tuntas \\
\hline 2 & 90 & 2 & $11,11 \%$ & Tuntas \\
\hline
\end{tabular}




\begin{tabular}{|c|c|c|c|l|}
\hline 3 & 80 & 5 & $27,78 \%$ & Tuntas \\
\hline 4 & 70 & 7 & $38,89 \%$ & Tuntas \\
\hline 5 & 60 & 2 & $11,11 \%$ & Tidak Tuntas \\
\hline Jumlah & & 18 & $100 \%$ & \\
\hline
\end{tabular}

Tabel 4 menunjukkan bahwa ketuntasan belajar terhadap materi kenampakan negara-negara Asia Tenggara dengan pembelajaran Snowball Throwing pada siklus I adalah sebanyak 16 anak (88,88\%). Secara klasikal tuntas belajar karena jumlah siswa yang telah mencapai KKM 70 melebihi indikator 85\%.

Berdasarkan hasil pengamatan selama pembelajaran siklus II dapat ditarik beberapa kesimpulan seperti berikut ini. a) Kegiatan pembelajaran berlangsung sesuai dengan rencana pelaksanaan pembelajaran, b) Diskusi siswa sudah terlaksana dengan baik sehingga susana kelas menjadi aktif, kreatif dalam suasana menyenangkan. c) Ketuntasan klasikal tercapai 88,88\% sebanyak 16 siswa dari 18 siswa telah memperoleh nilai di atas KKM 70.

Keberhasilan pembelajaran memahami kenampakan alam dan keadaan sosial negara tetangga dengan Pembelajaran Snowball Throuwing dapat dilihat dari perubahan tingkat pemahaman siswa terhadap bahan ajar. Tingkat pemahaman siswa terhadap bahan ajar memahami memahami kenampakan alam dan keadaan sosial negara tetangga dapat diukur dengan tes tulis baik pilihan ganda maupun uraian. Nilai hasil tes merupkan gambaran tingkat penguasaan siswa terhadap materi memahami kenampakaan alam dan keadaan sosial negara tetangga tersebut. Keberhasilan siswa itu dapat diketahui dari adanya perubahan nilai. Perubahan nilai dapat diketahui dengan cara membandingkan hasil belajar siswa baik secara orang perseorangan ataupun secara kelompok berdasarkan rata-rata nilai pada kondisi awal, siklus I dengan rata-rata nilai pada siklus II. Perbandingan nilai hasil belajar kondisi awal, siklus 1 dan siklus 2 dapat dilihat pada diagram 1 berikut ini.

Diagram 1 Perbandingan hasil tes siswa dalam Pembelajaran Snowball Throwing

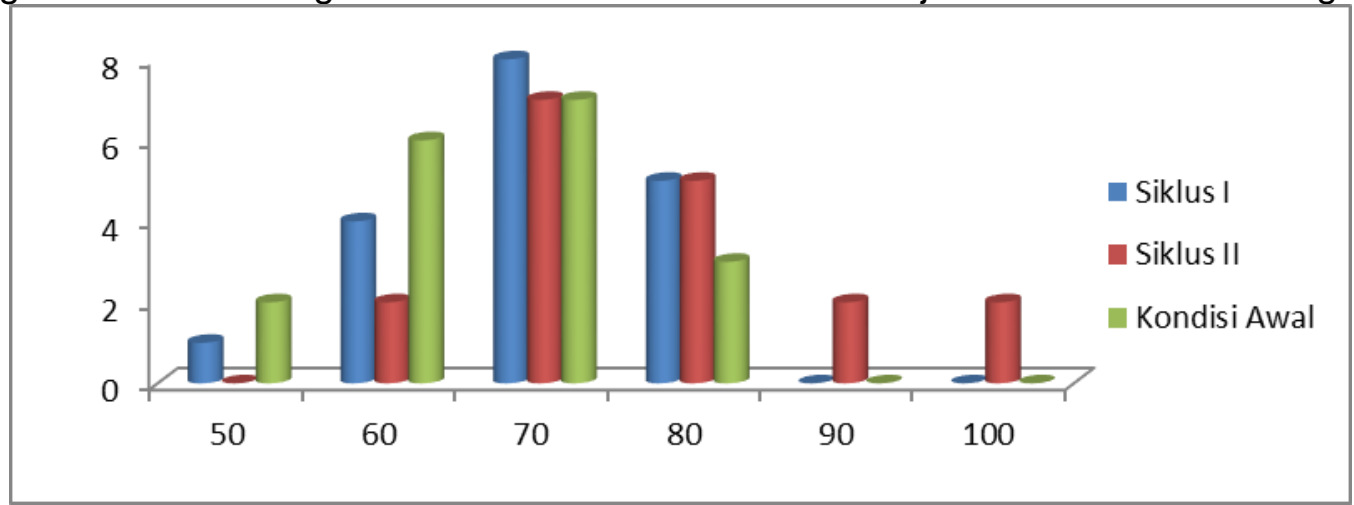

Diagram 1 menunjukkan bahwa pada kondisi awal siswa yang mendapat nilai di bawah KKM 70 cukup banyak yaitu 8 anak ( $44 \%$ ), pada siklus I siswa yang mendapat nilai di bawah KKM sebesar 70 ada 5 anak (27\%). Pada Siklus II siswa yang mendapat nilai di bawah KKM hanya 2 anak (11\%). Siswa yang mendapat nilai sama dengan dan lebih tinggi daripada KKM pada kondisi awal sebanyak 10 anak (56\%), pada siklus I sebanyak 13 anak (73\%), pada siklus II sebanyak 16 anak (89\%). Nilai rata-rata terjadi peningkatan, pada kondisi awal 66,11, nilai rata-rata siklus I sebesar 69,44 sedangkan nilai rata-rata siklus II sebesar 77,22.. Nilai rata-rata kondisi awal dan siklus I lebih kecil daripada KKM 70. Nilai rata-rata siklus II lebih besar daripada KKM sebesar 70.

Tingkat ketuntasan siswa didasarkan pada peroleh nilai dibandingkan dengan KKM sebesar 70 . Siswa dinyatakan tuntas bila memperoleh nilai sama atau lebih tinggi 
daripada KKM. Perbandingan ketuntasan belajar dapat dilihat pada diagram 2 berikut ini.

Diagram 2. Perbadingan Tingkat Ketuntasan Belajar kondisi awal, siklus 1 dengan siklus 2

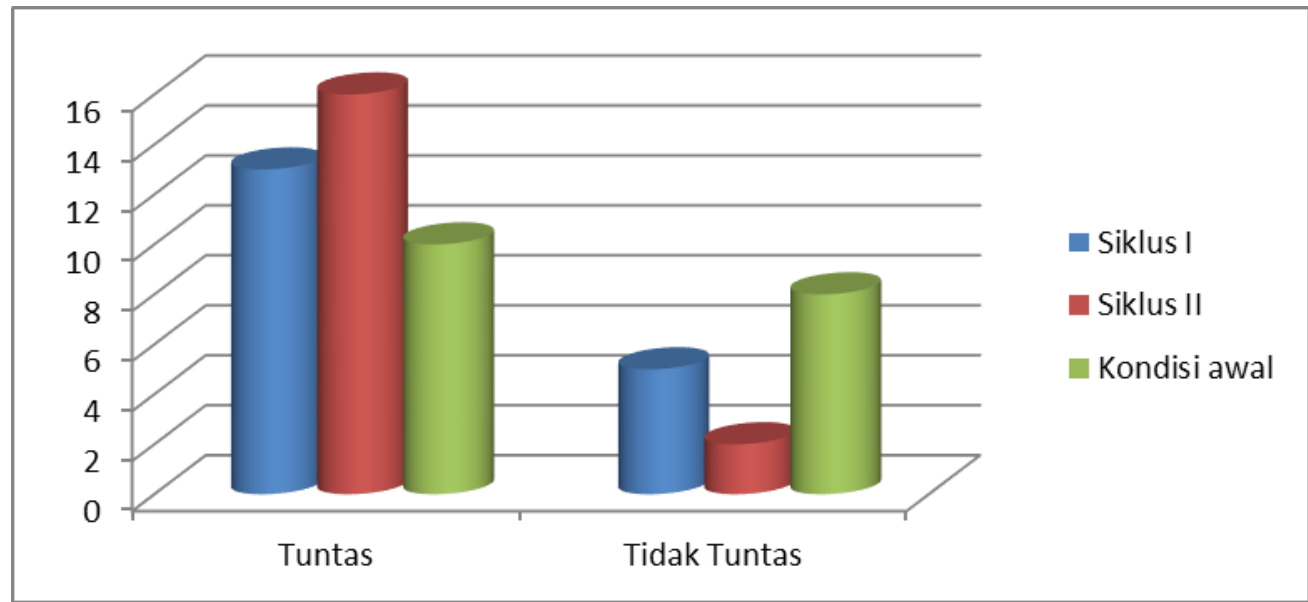

Berdasarkan diagram 4.2 siswa yang telah tuntas pada kondisi awal sebanyak 10 anak (56\%) yang belum tuntas sebanyak 8 anak (44\%), pada siklus I ketuntasan mencapai 13 anak (73\%) yang belum tuntas sebanyak 5 anak (27\%). Sedangkan pada siklus II siswa yang telah tuntas sebanyak 16 anak (89\%) yang belum tuntas sebanyak 2 anak (11\%). Berdasarkan diagram 4.2 tersebut dapat dinyatakan bahwa telah terjadi peningkatan yang cukup siknifikan. Jumlah siswa yang tuntas belajar dalam memahami kenampakan alam dan keadaan sosial negara-negara tetangga Indonesia dari 10 anak pada kondisi awal, terjadi peningkatan pada siklus I menjadi 13 anak dan pada siklus II siswa yang tuntas belajar menjadi 16 anak.. Berdasarkan data tersebut berarti terjadi peningkatan persentase ketuntasan dari kondisi awal dengan siklus II sebesar $33,33 \%$.

\section{KESIMPULAN}

Berdasar hasil penelitian tindakan kelas terhadap Pembelajaran aktif model Snowball Throwing yang sudah dilakukan sebanyak 2 siklus, dapat dikemukakan bahwa: Hasil evaluasi pada siklus I menunjukkan bahwa penguasaan siswa terhadap kenampakan alam dan keadaan sosial negara-negara tetangga Indonesia masih kurang karena nilai rata-rata 69,44. Nilai rata-rata masih di bawah KKM 70. Ketuntasan belajar secara klasikal hanya $73 \%$ belum mencapai indikator se-kurang-kurangnya $85 \%$. Pada siklus II nilai rata-rata siswa sebesar 77,22 . Nilai rata-rata sudah melebihi KKM 70. Ketuntasan belajar sebesar $89 \%$ telah melebihi kriteria indikator penelitian sebaesar $85 \%$. Berdasarkan data tersebut dapat disimpulkan bahwa pembelajaran Snowball Throwing dapat meningkatkan hasil belajar IPS materi kenampakan alam dan keadaan sosial negara-negara tetangga pada siswa kelas VI semester 1 tahun pelajaran 2016-2017 di SDN 1 Kamulan.

\section{DAFTAR RUJUKAN}

Arikunto, Suharimi. 2014. Penelitian Tindakan Kelas. Jakarta: PT Bumi Aksara.

B. Uno Hamzah. 2007. Model Pembelajaran, Menciptakan Proses Belajar Mengajar Yang Kreatif Dan Efektif. Jakarta: Bumi Aksara

Huda, Miftahul. 2016. Model-Model Pengajaran dan Pembelajaran, isu-isu metodis dan paragdimatis. Yogyakarta: Pustaka Pelajar.

Sanjaya, Wina. 2006. Strategi Pembelajaran beroreintasi Standar Proses Pendidikan. Jakarta: Kencana Prenadamedia Goup.

Supririyono, Agus. 2009. Cooperative Learning, Teori dan Aplikasi Paikem. Yogyakarta: Pustaka Pelajar. 